http://dx.doi.org/10.4314/jae.v18i2.9

\title{
Assessment of ICT Utilization in Agriculture Across-Gender in Enugu-Ezike Agricultural Zone of Enugu State, Nigeria
}

\author{
Enwelu I. A. , K. O.Uramah, A. N. Asadu and J. Chah \\ Department of Agricultural Extension \\ University of Nigeria, Nsukka, Enugu State, Nigeria \\ *email: enwachonamin@yahoo.com, Mobile Phone: +2348035090033
}

\begin{abstract}
The study assessed ICT utilization in agriculture across gender in Enugu-Ezike agricultural zone of Enugu State, Nigeria. Ninety (90) rural farmers (across gender) were interviewed for the purpose of eliciting information. The respondents had high access to mobile phone $(\bar{x}=1.90)$, radio sets $(\bar{x}=1.92)$ and television $(\bar{x}=1.18)$. Agricultural information on available farm inputs was obtained and shared through radio by men (30.0\%), youth (26.7\%) and women (23.3\%) and through mobile phone by men (31.1\%), youth (27.8\%) and women (25.6\%). More men than youth and women perceived factors faciltating the effective utilization of ICT in agriculture. However, out of $83.3 \%$ of the respondents who perceived that adequate power supply was one of the factors that could facilitate ICT utilization in agriculture, there were more women (28.9\%) compared to men (27.8\%) and youth (26.7\%). The study recommended among other things appropriate policies that will enhance ICT utilization in agriculture such as ICT packages that are compatible with the culture of the people and adequate ICT infrastructure that will ensure availability of internet and network services at affordable rates.
\end{abstract}

Keywords: ICT, agriculture, gender, Enugu-Ezike

\section{Introduction}

Agriculture as a primary production sector should be modernized to boost food production in any nation. The modernization process can be enhanced through the use of research generated technologies to solve the problems inherent in agriculture. There are about 15 agro-based research institutes under the supervisory body of agricultural research council of Nigeria (ARCN), which generate feasible, adaptable and socio-culturally compatible technologies for dissemination to millions of end users across various agro-ecological zones of the country (Amusa and Adeniyi, 2012). Information on these technologies can be effectively and efficiently disseminated to end users in a comprehensible and utilizable manner with the help of extension agencies.

It is a well-known fact that in the nation's agricultural research institutes, there exist huge volumes of completed research studies, which are not readily accessible to extension agencies and rural farmers. Meanwhile access to information holds the key to successful agricultural development. Information communication technologies (ICTs) in recent years have witnessed major changes and are emerging as a powerful tool for accelerating agricultural growth in a developing country like Nigeria. According to Okeh (2002), the 
literature has stressed that the quality of life of rural dwellers can be highly improved by effective provision of relevant information to rural communities.

Improved communication and information access is therefore very germane in the socioeconomic development of any nation. Hence, looking at the afore-stated scenario, ICT has the potentials to deliver useful agricultural information to farmers in an adaptable way. ICTs are diverse set of technological tools and resources used to communicate, disseminate, store, and manage information (Blurton 1999). Nwodo (2003) describes ICTs as a generic name used to refer to a number of communication hardwares adopted in ensuring instant dissemination of information and social values across the globe. They encompass a range of rapidly evolving technologies and they include telecommunication technologies (telephony, cable, satellite, TV and radio, computer-mediated conferencing, video conferencing) as well as digital technologies (computers, information networks, internet, World Wide Web, intranets and extranets) and software applications (Chisenga, 2006).

ICTs help in performing tasks quickly, efficiently and comprehensively as well as facilitate the flow of large volumes of information to a wide audience across numerous geographical locations. Though ICTs are not a panacea to agricultural and rural development, they have the potential of bridging the information gap for rural farmers with respect to innovative practices, government policies, credit facilities, accessing markets and acting as an effective tool for policy advocacy. They provide equal opportunity to all ages and by so doing unfold unlimited opportunities across gender. ICTs also enhance the dissemination of agricultural information to farmers and help in transforming agriculture and making it an attractive and lucrative sector. Despite this, agriculture is still not perceived as an attractive industry for people especially the active population in rural areas.

There is widespread belief that while ICTs are a "new social and economic force in the world economy," their adoption and utilization in developing countries are constrained among other problems by inadequate infrastructure, limited human resource capacity, absence of national policies and low ICT literacy (Moyo, 1996). However, there is strong indication that the use of ICTs may be widespread among men, women and youth in other areas like family contact and social media, but their use in agriculture across gender in some rural areas of Enugu State is not yet well established, hence the need for this study.

On the basis of foregoing, the study assessed ICT utilization in agriculture across gender in Enugu-Ezike agricultural zone of Enugu State, Nigeria. Specifically, the study determined the level of access of ICT facilities to rural farmers; ascertained the extent of utilization of ICT facilities in agriculture across gender; and examined respondents'perception of factors that could facilitate effective utilization of ICT in agriculture (across gender). 


\section{Methodology}

The study was carried out in Enugu-Ezike Agriculture zone of Enugu State. It is located in the humid tropical rain forest zone. Within the zone, there exist different network masts built by different network providers in the country. Many telephone, computer and network services are scattered within the heart of the zone.

The area has favourable conditions for agricultural activities. Thus, most of the inhabitants are either full time or part time farmers. Some of the people are animal farmers while some are engaged in crop farming or both. Some of the crops produced in the zone include: cassava, maize, cocoyam, yam etc. They are also involved in production of poultry, piggery, fishery, sheep, goat, cattle etc

The population for the study comprised all rural farmers (including men, women and youth) in Enugu-Ezike Agricultural Zone of Enugu state, Nigeria. A multi-stage random sampling procedure was employed in selecting the respondents. In the first stage, all the three blocks within the zone were selected. The blocks were Igbo-eze North, Igbo- south and Udenu blocks. In the second stage, two circles were randomly selected from each of the three blocks. The selected circles for each of the blocks were listed as follows: for for Igbo-eze North block (Uda and Aji), Igbo-eze south block (Iheaka and Uhunowere) and for Udenu (Obollo afor and Orba). In the third stage, 15 farmers (made up of 5 men, 5 women and 5 youth) were purposively selected to give a total of 90 farmers for the study. Data for the study was gathered through structured interview schedule. Data generated from the study were presented using percentage and mean scores.

The level of rural farmers' access to ICT facilities was determined by asking the respondents to rate their level of access on a three- point Likert-type scale of: high access (2), low access (1) and not accessible (0). Respondents with mean value equals to 1 or greater than 1 were regarded as having access while those with mean value less than 1 were regarded as having low access to ICTs facilities. ICT utilization in agriculture across gender was ascertained by asking the respondents to indicate the selected ICT tool they use in obtaining and sharing agricultural information from the list provided. Respondents' perception of factors that facilitate effective utilization of ICT in agriculture across gender was ascertained by asking them to indicate factors that would facilitate ICT utilization from the list of possible factors.

\section{Results and Discussion}

\section{Level of rural farmers' access to ICT facilities}

Data in Table 1 reveal that the respondents had high access to two traditional ICT toolsradio sets and television and one modern ICT tool- mobile phone. On the contrary, they had low access to traditional ICT facilities such as: posters, newspaper, magazine, video player and leaflet. Also, they had low access to modern ICT tools like: facebook, flash, flash drive, internet, email and twitter.

The finding is similar to that of Wole (2009) which show that the most common ICT facilities that the respondents in the two locations studied have access to are radio and 
television followed by cell/mobile phones. The implication of this finding is that they do not have access to ICT facilities that can enable them have access to wide range of agricultural information through out the globe such as the internet (facebook, email and twitter). They may have low access to such facilities probably because cannot afford to pay for them. According to international telecommunications union (ITU) (2003) the overall ability of individuals in a country to access and use ICTs is based on digital access index (DAl) which is built around four fundamental vectors that impact a country's ability to access ICTs: infrastructure, affordability, knowledge and quality and actual usage of ICTs.

Similarly, Ozor and Madukwe (2009) argue that agricultural development in most developing countries like Nigeria has been hampered by low level of agricultural information exchange as a result of limited access to current and relevant information in the form of primary documents machine-readable databases. They maintain that giving farmers access to a variety of information sources, which are accessible, affordable, relevant and reliable is the ultimate aim of providing agricultural information services.

Table 1: Distribution of respondents according to level of rural farmers' access to ICT facilities

\begin{tabular}{lcc}
\hline ICT facilities & Mean score & Standard deviation \\
\hline Mobile phone & $1.90^{*}$ & 0.337 \\
Computer & 0.26 & 0.487 \\
Internet & 0.11 & 0.316 \\
E-mail & 0.12 & 0.362 \\
Newsletter & 0.10 & 0.337 \\
Posters & 0.77 & 0.750 \\
Video player & 0.60 & 0.731 \\
Video recorder & 0.37 & 0.626 \\
Scanner & 0.17 & 0.375 \\
Twitter & 0.09 & 0.286 \\
Face book & 0.13 & 0.373 \\
CD/DVD & 0.34 & 0.639 \\
Digital camera & 0.18 & 0.439 \\
Radio sets & $1.92^{*}$ & 0.308 \\
TV & $1.18^{*}$ & 0.663 \\
Newspaper & 0.67 & 0.821 \\
Bulletin & 0.34 & 0.603 \\
Leaflet & 0.38 & 0.663 \\
Flash & 0.13 & 0.373 \\
Flash drive & 0.12 & 0.362 \\
Magazine & 0.63 & 0.661 \\
\hline
\end{tabular}

$\left({ }^{*}\right)$ ICT facilities with high access 


\section{Selected ICT tools used in obtaining and sharing agricultural information}

Data in Table 2 show that majority of the respondents used radio to obtain and share information on the following agricultural activities: available farm input .e.g fertilizer (80\%), where to procure planting material (64.4\%) and best varieties of crop/animals to use $(60 \%)$. A few proportion of the respondents used radio to obtain information on method of pests and disease control (21.2\%). Also, majority of the respondents used mobile phone to obtain and share information on some agricultural activities like available farm input .e.g fertilizer (84.5\%), best varieties of crop/animals to use $(66.7 \%)$ and where to procure planting material $(63.3 \%)$ while a few proportion of the respondents used mobile phone to obtain information on method of pests and disease control (33.3\%). Only small proportion of the respondents used television to obtain and share information on the following agricultural activities: available farm input .e.g fertilizer (43.3\%), where to procure planting material (38.9\%) and best varieties of crop/animals to use (37.8\%). The least proportion $(17.8 \%)$ of the respondents used television to obtain and share information on available subsidies for major inputs and how to access them.

The finding reveals that mobile phone and radio sets are mostly utilized by rural farmers in obtaining and sharing information of most farm activities while television is not used to the same extent probably because of their inability to purchase it. The increasing use of mobile phones by farmers will help in transformation of Nigerian agriculture. This is because it is relatively cheap and easy to use even by illiterate farmers. According to Adesola (2012), another phenomenon that is becoming more and more relevant today is the use of mobile technology for broadened participation of civil society in decisionmaking process. Due to their availability, simple use and cost-effectiveness, mobile phones are more and more considered by governments and NGOs as a powerful means to engage citizens in economic, political and social debates. According to Onunga (2007), the number of mobile cellular subscribers around the world is growing rapidly. Thus, the number of mobile cellular subscribers rose from just 12 million in 1995 to over 1.15 billion in 2005, at the growth rate of 58 per cent per year in the developing economies.

Table 2: Percentage distribution of selected ICT tools used in obtaining and sharing agricultural information

\begin{tabular}{|c|c|c|c|}
\hline Agricultural information on: & 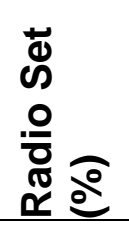 & 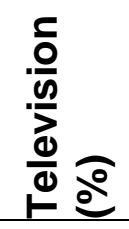 & 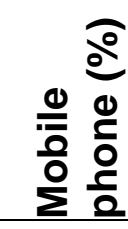 \\
\hline Where to procure planting material & 64.4 & 38.9 & 63.3 \\
\hline $\begin{array}{l}\text { Available farm input .e.g fertilizer, agrochemicals, } \\
\text { improved seeds e.tc }\end{array}$ & 80.0 & 43.3 & 4.5 \\
\hline $\begin{array}{l}\text { Available subsidies for major inputs and how to access } \\
\text { them }\end{array}$ & 24.5 & 17.8 & 8 \\
\hline Method of pests and disease control & 21.2 & 18.9 & 33.3 \\
\hline Best varieties of crop/animals to use & 60.0 & 37.8 & 6.7 \\
\hline
\end{tabular}


Creative Commons User Licence: CC BY-NC-ND

Abstracted by: EBSCOhost, Electronic Journals Service (EJS),

Google Scholar, Directory of Open Access Journals (DOAJ),

Journal Seek, Scientific Commons, and

Food and Agricultural Organization (FAO)

Different agricultural programmes

Government policies on agricultural matters

Improved agro-management practices
Journal of Agricultural Extension

Vol.18 (2) December, 2014

ISSN 1119-944X

http://journal.aesonnigeria.org http://www.ajol.info/index.php/jae

$\begin{array}{lll}58.9 & 30.0 & 47.8\end{array}$

$38.9 \quad 17.8 \quad 37.8$

$51.1 \quad 24.4 \quad 45.6$

Multiple responses 


\section{Agricultural information obtained and shared by use of radio across gender}

In Table 3, more of men (30.0\% and youth (26.7\%) obtained and shared information through radio on available farm inputs than women $(23.3 \%)$. The trend is similar for other activities, like where to procure planting material(men-24.4\%; youth-21.1\%; women$18.9 \%$ ), best varieties of crop/animals to use (men-23.3\%; youth-18.9\%; women-17.8\%), different agricultural programmes (men-22.2\%; youth-21.1\%; women-15.6\%), improved agro-management practices (men-20.0\%; youth-16.7\%; women-14.4\%) etc

This finding implies that higher proportion of men than youth uses radio as ICT tool in obtaining and sharing agricultural information. Women were least in terms of use of radio in almost all the information areas studied. This finding is similar to Wole (2009) whose study reveals that male respondents are able to use most of the ICTs than their women counterparts. This could be because they are mostly engaged with household chores. Hence, because of low ICTs use by women (who are major role players in agricultural activities), they tend to contribute lesser than what they could have contributed if they had access to other innovative ways of carrying out some of these operations. As a result, Masuki, Kamugisha, Mowo, Tanui, et al. (2010) state that improvement of agricultural productivity will be realized when rural women are able to access agricultural information. Generally, the use of radio for obtaining and sharing agricultural information is available but not impressive in the zone.

Table 3: Percentage distribution of agricultural information obtained and shared by use of radio across gender

\begin{tabular}{llll}
\hline Agricultural information on: & Men (\%) & Woman (\%) & Youth (\%) \\
\hline $\begin{array}{l}\text { Where to procure planting material } \\
\text { Available farm inputs .e.g. fertilizer, agrochemicals, }\end{array}$ & 24.4 & 18.9 & 21.1 \\
improved seeds e.tc & 30.0 & 23.3 & 26.7 \\
$\begin{array}{l}\text { Available subsidies for major inputs \& how to access } \\
\text { them }\end{array}$ & 10.0 & 5.6 & 8.9 \\
Method of pests and disease control & 8.9 & 5.6 & 6.7 \\
Best varieties of crop/animals to use & 23.3 & 17.8 & 18.9 \\
Different agricultural programmes & 22.2 & 15.6 & 21.1 \\
Government policies on agricultural matters & 16.7 & 10.0 & 12.2 \\
Improved agro-management practices & 20.0 & 14.4 & 16.7 \\
\hline
\end{tabular}

Multiple responses

\section{Agricultural information obtained and shared by use of television across gender}

Data in the Table 4 show that men, women and youth used television in obtaining and sharing agricultural information on the following farm activities: available farm inputs (men-18.9\%; youth-13.3\%; women-11.1\%), where to procure planting material(men$16.7 \%$; youth-12.2\%; women-10.0\%), best varieties of crop/animals to use (men-15.6\%; youth-13.3\%; women-8.9\%), different agricultural programmes (men-13.3\%; youth-10.0\%; women-6.7\%), improved agro-management practices (men-12.2\%; youth-7.8\%; women$4.4 \%$ ), method of pests and disease control (men-10.0\%; youth-5.6\%; women-3.3\%), government policies on agricultural matters (men-8.9\%; youth-5.6\%; women-3.3\%) and 
available subsidies for major inputs and how to access them (men-7.8\%; women-5.6\%; youth-4.4\%).

Among the selected ICT tools studied, television is the least utilized. Again, the finding reveals that greater proportion of men than youths and women uses television in obtaining and sharing agricultural information. This may be because of their orientation towards using television which some of them see as something that should be done by men and probably the young ones. It may also be as a result of social or economic problem in which women and youth are usually more affected than men.

Table 4: Percentage distribution of agricultural information obtained and shared by use of television across gender

\begin{tabular}{|c|c|c|c|}
\hline Agricultural information on: & Men(\%) & Women (\%) & Youth(\%) \\
\hline Where to procure planting material & 16.7 & 10.0 & 122 \\
\hline $\begin{array}{l}\text { Available farm inputs .e .g fertilizers, agrochemicals, } \\
\text { improved seeds e.tc }\end{array}$ & 18.9 & 11.1 & 13.3 \\
\hline $\begin{array}{l}\text { Availability subsidies for major inputs \& how to access } \\
\text { them }\end{array}$ & 7.8 & 5.6 & 4.4 \\
\hline Method of pests and disease control & 10.0 & 3.3 & 5.6 \\
\hline Best varieties of crop/animals to use & 15.6 & 8.9 & 13.3 \\
\hline Different agricultural programmes & 13.3 & 6.7 & 10.0 \\
\hline Government policies on agricultural matters & 8.9 & 3.3 & 5.6 \\
\hline Improved agro-management practices & 12.2 & 4.4 & 7.8 \\
\hline
\end{tabular}

Multiple responses

\section{Agricultural information obtained and shared by use of mobile phone across gender}

The results of the study in Table 5 showed that higher proportion of men obtained and shared agricultural information by use of mobile phone than youth and women in all the information areas except in method of pests and disease control where youth (13.3\%) has a higher proportion than men (11.1\%) and women had only $8.9 \%$. The findings also reveal that the use of mobile phone in obtaining and sharing agricultural information although slightly higher than other selected ICTs but its usage is generally low among men, youth and women. The implication of this finding is that vital information that can easily be sourced through the use of mobile phone is not utilized. The problem can be as a result of lack of phone directory of farmers in the country from which farmers can contact their fellow farmers. On the other hand the low use of mobile phone by women may be as a result of of their low income level, operating skill, and their general lackadaisical attitude towards the use of mobile phone as may be observed in some who usually keep their phones inside their hand bags. 
Table 5: Percentage distribution of agricultural information obtained and shared by use of mobile phone across gender

\begin{tabular}{lccc}
\hline Agricultural information on: & $\begin{array}{l}\text { Men } \\
(\%)\end{array}$ & $\begin{array}{c}\text { Woman } \\
(\%)\end{array}$ & $\begin{array}{l}\text { Youth } \\
(\%)\end{array}$ \\
\hline $\begin{array}{l}\text { Where to procure planting material } \\
\text { Available farm inputs .e.g fertilizer, agrochemicals, }\end{array}$ & 24.4 & 17.8 & 21.1 \\
improved seeds e.tc & 31.1 & 25.6 & 27.8 \\
Available subsidies for major inputs \& how to access them & 16.7 & 10.0 & 11.1 \\
Method of pests and disease control & 11.1 & 8.9 & 13.3 \\
Best varieties of crop/animals to use & 26.7 & 18.9 & 21.1 \\
Different agricultural programmes & 18.9 & 13.3 & 15.6 \\
Government policies on agricultural matters & 15.6 & 10.0 & 12.2 \\
Improved agro-management practices & 17.8 & 11.1 & 16.7 \\
\hline
\end{tabular}

Multiple responses

\section{Perceived factors that could facilitate effective utilization of ICTs in agriculture (across gender)}

The results in Table 6 indicate adequate power supply is perceived by most of the respondents $(83.3 \%)$ ) to be an important factor faciltating the effective utilization of ICT in agriculture. Meanwhile, there were women (28.9\%) compared to men $(27.8 \%)$ and youth $(26.7 \%)$ who shared the view. However, out of several respondents ( $78.9 \%)$ who perceived that implementation of policies will enhance ICT development in rural areas, more of them (27.8\%) were men compared to youth $(26.7 \%)$ and women $(24.4 \%)$. Furthmore, out of $78.9 \%$ who perceived that rural people can be motivated by subsidizing the price of ICT tools, more (30.0\%) were men compared to youth $(25.6 \%)$ and women (23.3\%). In case of ensuring availability of internet and network services by the service provider, more youth (27.8\%) compared to women (25.6\%) and men (24.4\%) perceived the factors to facilitate effective utilization of ICTs in agriculture. Other factors like Organizing training on ICT packages(76.7\%), value reorientation of the people towards the use of ICTs (76.7\%) and introducing ICT packages that are simple to understand $(71.1 \%)$ were perceived by more of men $(27.8 \%, 28.9 \%$ and $26.7 \%)$ than youth $(26.7 \%$, $21.1 \%$ and $24.4 \%)$ and women $(22.2 \%, 26.7 \%$ and $20.0 \%)$ respectively. However, providing adequate ICT tools in rural areas (74.5\%) was perceived by more women $(27.8 \%)$ than men $(25.6 \%)$ and youth $(21.1 \%)$.

The implication of this is that men is likely to optimally use ICT tools in obtaining and sharing agricultural information if factors like prices of ICT tools and power supply are addressed. Again, the higher proportion of youth that perceived such factors as ensuring availability of internet and network services by the service provider may be to facilitate their access to social media interaction in other issues not primarily agricultural. However, the major factors perceived by most of the respondents that can facilitate effective utilization of ICTs in agriculture are provision of infrastructure and ICT facilities. This finding is in agreement with the finding of Aina (2007) which states that the dissemination of agricultural information in Africa is affected by lack of basic infrastructure, such as good power supply, good road network, pipe borne water etc. 
Table 6: Distribution of perceived factors that facilitate effective utilization of ICT in Agriculture (across gender)

\begin{tabular}{|c|c|c|c|c|}
\hline Perceived factors & $\begin{array}{l}\text { Men } \\
(\%)\end{array}$ & $\begin{array}{l}\text { Women } \\
(\%)\end{array}$ & Youth (\%) & $\begin{array}{l}\text { Total } \\
(\%)\end{array}$ \\
\hline Adequate power supply & 27.8 & 28.9 & 26.7 & 83.3 \\
\hline $\begin{array}{l}\text { Implement policies that will enhance ICT } \\
\text { development in rural areas }\end{array}$ & 27.8 & 24.4 & 26.7 & 78.9 \\
\hline $\begin{array}{l}\text { Motivating the rural people by subsidizing the } \\
\text { price of ICT tools }\end{array}$ & 30.0 & 23.3 & 25.6 & 78.9 \\
\hline $\begin{array}{l}\text { Availability of internet and network services by the } \\
\text { service provider }\end{array}$ & 24.4 & 25.6 & 27.8 & 77.8 \\
\hline Organizing training on ICT packages & 27.8 & 22.2 & 26.7 & 76.7 \\
\hline $\begin{array}{l}\text { Value reorientation of the people towards the use } \\
\text { of ICTs }\end{array}$ & 28.9 & 26.7 & 21.1 & 76.7 \\
\hline Providing adequate ICT tools in rural areas & 25.6 & 21.1 & 27.8 & 74.5 \\
\hline $\begin{array}{l}\text { Introducing ICT packages that are simple to } \\
\text { understand }\end{array}$ & 26.7 & 20.0 & 24.4 & 71.1 \\
\hline $\begin{array}{l}\text { ICT packages that is compatible with the culture } \\
\text { of the people }\end{array}$ & 25.6 & 21.1 & 22.2 & 68.9 \\
\hline
\end{tabular}

\section{Conclusion}

Based on the findings of the study, the following conclusions were made: (1) With the exception of traditional ICTs such as radio and television and modern ICT like mobile phone, rural farmers' access to ICTs in agriculture was low in Enugu-Ezike agricultural zone (2)Traditional ICTs namely radio and television and modern ICT like mobile phone were mostly used in obtaining and sharing agricultural information such as available farm inputs, where to procure planting material etc (3) More proportion of men than youth and women utilized selected ICT tools in obtaining and sharing agricultural information (4) Some perceived factors that could facilitate effective utilization of ICTs in agriculture were provision of infrastructure and ICT facilities

\section{Recommendations}

The following recommendations were made based on the conclusions: (1) Promote establishment of community multimedia centres (CMCs) which can offer affordable or free computer and internet access, training and possibilities to connect with more remote communities through the use of local radio. (2) Make appropriate policies that will enhance ICT access and utilization in rural areas through provision of infrastructure and ICT packages that are compatible with the culture of the people (3) Organize gender sensitive ICT programmes in rural areas that will encourage men, women and youth to use ICTs in agriculture. 


\section{References}

Adesola, S. A. (2012). Entrenching democracy and good governance: the role of ICT Mediterranean Journal of Social Sciences, Special Issue, Vol. 3, No. 15. Pp. 80-87 Mediterranean Center of Social and Educational Research

Aina, L.O. (2007). Globalisation and Small- Scale Farming in Africa: What role for Information Centres? World libraries and information congress 73rd IFLA General conference and council. Durban, South Africa.

Amusa T. and Adeniyi Suraju, 2012 Agricultural extension: Need for ICT. Retrieved from http://tribune.com.ng/index.php/letters/40848-agricultural-extension-need for-ict

Blurton, C. (1999). Chapter 2: New directions in education. In: UNESCO's World communication and information 1999-2000. Paris: UNESCO: 46-61

Chisenga, J. (2006). Information and communication Technologies: Opportunities and Challenges For National and University Libraries in Eastern, Central and Southern Africa. Keynote paper presented at the standing conference of African National and University libraries of Eastern, Central and Southern Africa (SCANUL-ECS), The courtyard Hotel, Dares Salaam, Tanzania, 9-10 July.

International Telecommunications Union (ITU) (2003). World telecommunication development report:Access Indicators for the information society, pp. 12-30.

Masuki, K.F., Kamugisha, R., Mowo, J.G., Tanui, J., Tukahirwa, J., Mogoi, J. and Adera, E.O. (2010). Role of mobile phones in improving communication andinformation delivery for agricultural development: Lessons from South Western Uganda. ICT and development-research voices from Africa. International Federation for Information Processing (IFIP) technical commission 9-relationship between computers and society. Workshop at Makerere University, Uganda, 22-23 March.

Moyo L.M. (1996). Information technology strategies for Africa's survival. Information technology for development, 7: 17-27. IOS Press

Nwodo G.C. (2003).Using Information and Communication Technologies (ICTs) to Check Electoral Fraud in Africa. A paper presented at the Biennal Conference of African Council for Communication Education (ACCE), held in Abuja, 9th-13th August.

Okeh, E. (2002). Change agent and information provision in rural communities: The case of selected Nigerian communities. Gateway Journal 5(2): pp. 54-60.

Onunga, J. (2007). Kenya World Information Society Report 2007, jointly published by ITU and UNCTA 
Ozor, N. and Madukwe, M. C. (2009). Role of information communication Technology in agricultural development. In Echezona, B. C. (ed.). General Agriculture: Principles and Practices, Faculty of Agriculture, University of Nigeria, Nsukka. Pp. 20-24

Wole, M. O. (2009). Analysing socio-demographic differences in access and use of ICTs in Nigeria using the capability approach. Issues in Informing Science and Information Technologies, Volume 6 